\title{
PEMAKSIMALAN TEKNOLOGI INFORMASI \\ UNTUK MENINGKATKAN KUALITAS PENDIDIKAN \\ MELALUI SUPERVISI PENDIDIKAN
}

\author{
ARTIKA MUTIARA SAIMA
}

EMAIL: artikamutiarasaima20@gmail.com

\begin{abstract}
ABSTRAK
Kemajuan teknologi informasi yang begitu cepat diharapkan bisa meningkatkan kualitas pendidikan di Indonesia Dalam dunia pendidikan teknologi informasi bisa membantu serta menunjang proses pembelajaran. Apalagi saat ini semua kegiatan proses pembelajaran bisa dilakukan secara online. Kemajuan teknologi informasi juga harus didukung oleh sumber daya manusia yang berkualitas. Dalam hal ini guru sangat berperan dalam pemanfaatan teknologi informasi dalam dunia pendidikan. Karena guru salah satu supervisor pendidikan yang akan mendorong majunya kualitas pendidikan di Indonesia. Namun kenyataannya kualitas guru di Indonesia belum memadai. Masih banyak guru yang tidak bisa menggunakan teknologi informasi dalam pembelajaran terkhususnya bagi guru yang sudah senior atau tua. Sebagai supervisor guru harus meningkatkan kualitas kinerjanya dalam menggunakan teknologi.Untuk meningkatkan kemampuan guru dalam menggunakan teknologi maka diperlukan pelatihan berkelanjutan untuk menggunakan teknolgi. Peran kapala sekolah sebagai supervisor juga diperlukan yaitu kepala sekolah wajib mengawasi, mengontrol, dan melakukan pendekatan kepada guru dalam hal penggunaan teknologi pada proses pembelajaran.
\end{abstract}

\section{Kata kunci : Teknologi, Kualitas, Pendidikan, Supervisi.}

\section{PENDAHULUAN}

Pada era modern dan kemajuan teknologi yang begitu pesat saat ini seharusnya bisa meningkatkan kualitas pendidikan di Indonesia. Teknologi digunakan diberbagai sendi kehidupan, karena mempermudah dan membantu kegiatan manusia. Dalam dunia pendidikan teknologi informasi bisa membantu serta menunjang proses pembelajaran. Apalagi saat ini semua kegiatan proses pembelajaran bisa dilakukan secara online. Salah satu prinsip pembelajaran pada kurikulum 2013 yaitu penerapan teknologi informasi secara terintegrasi yang dapat mengarahkan siswa berpikir kritis dan analitis. Hal tersebut selaras dengan apa yang diharapkan science educators in Kenyan, bahwa penggunaan teknologi informasi secara subtansial akan dapat membantu guru dalam mengembangkan pembelajaran agar lebih efisien dan efektif, sebab temuan dari negara negara maju telah menunjukkan kemampuan teknologi informasi dapat meningkatkan pengetahuan ilmiah siswa. Kemajuan teknologi informasi juga harus didukung oleh sumber daya manusia yang berkualitas

Dalam hal ini guru sangat berperan dalam pemanfaatan teknologi informasi dalam dunia pendidikan. Karena guru salah satu supervisor pendidikan yang akan mendorong majunya kualitas pendidikan di Indonesia. Namun kenyataannya kualitas guru di Indonesia belum 
memadai. Masih banyak guru yang tidak bisa menggunakan teknologi informasi dalam pembelajaran terkhususnya bagi guru yang sudah senior atau tua. Kebanyakan guru senior masih menggunakan metoda ceramah dalam pembelajaran. Banyak guru yang merasa terbebani dengan penggunaan teknologi informasi dalam pengajaran, karena guru ditutun legih kreatif dalam membuat media pembelajaran yang menggunakan teknologi. Tidak hanya rendahnya kualitas kinerja guru tetapi penggunaan teknologi informasi juga dipengaruhi kurangnya sarana dan prasarana yang ada, karena tidak semua sekolah memiliki computer dan jaringan internet. Berdasarkan uraian diatas, permasalahan dalam tulisan ini adalah (1) bagaimana permasalahan pemanfaatan teknologi informasi dalam dunia pendidikan di indonesia? (2) bagaimana alternative penyelesaian permasalahan teknologi informasi melalui supervisi pendidikan ? tujuan dari tulisan ini yaitu mengetahui permasalahan terkait teknologi informasi di dunia pendidikan dan mengetahui alternative penyelesaian permasalahan teknologi informasi melalui supervisi pendidikan di Indonesia.

\section{PEMBAHASAN}

\section{Permasalahan pemanfaatan teknologi informasi dalam dunia pendidikan}

Dengan kemajuan teknologi informasi yang begitu cepat seharusnya bisa meningkatkan mutu pendidikan di Indonesia. Karena dengan adanya teknologi informasi bisa membatu guru dalam proses pembelajaran agar lebih efektif dan efisien. Namun nyatanya kemajuan teknologi tidak selaras dengan kualitas guru yang ada karena masih banyak guru yang buta akan teknologi khusunya guru yang senior atau sudah tua. Banyak guru yang tidak paham penggunaan teknologi dalam pengajaran seperti guru dituntun lebih kreatif dalam pembuatan media pembelajaran yang berbasis teknologi.Berdasarkan (Sarjana, Agama, \& Negeri, 2017) diungkapkan bahwa Chaidar Husain mengemukakan masalah lain dalam pemanfaatan teknologi informasi dalam dunia pendidikan yaitu 1) masalah teknis, hal ini terkait dengan ketersediaan listrik yang memadai dan kestabilan jaringan internet, 2) secara psikologis guru terbebani untuk bisa mengajar dengan menggunakan media pembelajaran, 3) keterbatasan tenaga operasional untuk bisa memanfaatkan TIK, 4) kurangnya kompetensi guru dalam memanfaatkan teknologi informasi yang telah disediakan oleh sekolah yang terkadang dipengaruhi factor usia, 5) masalah pembiayaan.

\section{Alternative Penyelasaian Permasalahan Teknologi Informasi melalui Supervisi Pendidikan}

Berdasarkan (Kriten, Wacana, \& Pendidik, n.d.) Supervisi pendidikan berfungsi untuk mewujudkan kinerja mengajar yang baik bagi guru, kegiatan supervisi juga sebagai upaya memberi bantuan dan layanan untuk meningkatkan kualitas guru dalam mengajar menggunakan teknologi. Dalam upaya menyelesaiakan permasalahan yang berkaitan dengan teknologi informasi maka diperlukan alternative sabagai berikut :

Sebagai supervisor guru harus meningkatkan kualitas kinerjanya dalam menggunakan teknologi.

Dalam Sabandi (Sabandi, 2013) Peningkatan kualitas pembelajaran yang lebih efektif dapat dilakukan melalui peningkatan kompetensi guru yang dilakukan dengan pelatihan. Untuk meningkatkan kemampuan guru dalam menggunakan teknologi maka diperlukan pelatihan berkelanjutan untuk menggunakan teknolgi. Peran kapala sekolah sebagai supervisor juga diperlukan yaitu kepala sekolah wajib mengawasi, mengontrol, dan melakukan pendekatan kepada guru dalam hal penggunaan teknologi pada proses pembelajaran. Dan untuk guru yang sudah tua sendiri yang sulit untuk menggunkan computer sebaiknya pemerintah menyediakan 
tenaga teknisi computer untuk membantu guru tersebut jika mengalami kendala. Tidak hanya itu sebaiknya sebelum pemerintah menerapkan pembelajaran berbasis computer pemerintah terlebih dahulu harus menyediakan sarana dan prasarana yang memadai.

\section{PENUTUP}

\section{KESIMPULAN}

Berdasarkan pembahasan diatas dapat disimpulkan bahwa masih banyak permasalahan dalam hal penggunaan teknologi informasi dalam dunia pendidikan. Kemajuan teknologi informasi tidak didukung oleh kemampuan atau kualitas guru yang mengajar. Banyak guru yang tidak bisa menggunakan computer khususnya guru senior atau yang sudah tua tidak hanya itu penggunaan teknolgi informasi dalam pembelajaran tidak didukung oleh sarana dan prasarana yang memadai sehingga diperlukan alternative penyelasaiannya yaitu guru terlebih dahulu diberi pelatihan tentang computer dan pemerintah juga harus menyediakan tenaga teknisi TIK unruk membantu para guru yang kesulitan pemerintah juga harus menyediakan sarana dan prasarana yang memadai sebelum menggunakan pembelajaran yang berbasis teknologi.

\section{SARAN}

Seharusnya pemerintah sebelum menerapkan suatu kebijakan berupa pembelajaran berbasis teknologi terlebih dahulu melakukan sosialisasi, dan melengkapi segala kebutuhan untuk menunjang keberhasilan dari suatu kebijakan tersebut.

\section{REFERENSI}

Kriten, U., Wacana, S., \& Pendidik, P. (n.d.). Supervisi Pada Zaman Sekarang dan Masa Depan.

Sabandi, A. (2013). Supervisi Pendidikan Untuk Pengembangan Profesionalitas Guru Berkelanjutan. Jurnal Ilmiah Ilmu Pendidikan, XIII(2), 1-9.

Sarjana, P. P., Agama, I., \& Negeri, I. (2017). Kinerja Guru Pendidikan Agama Islam Di Sma Se Kota Palu Tahun 2017. 
